

Volume 11 No. 1 Juli 2020

\title{
PENERAPAN KOMUNIKASI DAN MANAJEMEN KONFLIK DI KANTOR MEDIA RAKYAT CIREBON
}

\section{APPLICATION OF COMMUNICATION AND CONFLICT MANAGEMENT IN OFFICE OF MEDIA RAKYAT CIREBON}

\author{
Cartono $^{1, a)}$, Karina Noer Meilawaty ${ }^{2, b)}$, Yasmine Muntazah ${ }^{3, c)}$ \\ ${ }^{1,2,3}$ Jurusan Komunikasi dan Penyiaran Islam, IAIN Syekh Nurjati Cirebon \\ ${ }^{\text {a) }}$-mail: cartonopr@gmail.com \\ b)e-mail: karinanoer43@gmail.com \\ c)e-mail: yasminemuntazah.ym@gmail.com
}

\begin{abstract}
ABSTRAK
Komunikasi dalam sebuah perusahaan sangat penting dan mempunyai pengaruh yang begitu besar. Salah satunya yaitu untuk menyelesaikan sebuah konflik. Berbagai konflik yang mungkin terjadi dalam sebuah perusahaan, sebagian besar dapat diselesaikan dengan komunikasi, sehingga perlu untuk memahami komunikasi organisasi dengan sangat baik. Tujuan dari penelitian ini yaitu untuk mengetahui penerapan komunikasi dan manajemen konflik di kantor media Rakyat Cirebon. Penelitian ini bersifat deskriptif dengan melakukan pendekatan kualitatif. Hasil dari penelitian ini yaitu adanya konflik personal dan konflik interpersonal. Konflik interest, konflik realistis dan konflik non realistis, konflik destruktif dan konflik konstruktif. Penyelesaian konflik di media Rakyat Cirebon ditempuh dengan cara tidak mengulangi kesalahan yang sama, membina komunikasi yang baik, menyadari perbedaan pendapat, menerima kritik dan pemberian motivasi.
\end{abstract}

Kata Kunci: Manajemen Konflik, Komunikasi, Konflik

\section{ABSTRACT}

Communication in a company is very important and has great effects. One of them is to resolve a conflict. Various conflicts that may occur within a company can largely be resolved by communication. Thus, it is necessary to understand 


\begin{abstract}
organizational communication very well. This research aimed to discover the application of communication and conflict management in the media office of Rakyat Cirebon. This research is descriptive in nature using a qualitative approach. The results of this study were personal conflicts and interpersonal conflicts, interest conflicts, realistic conflicts and non-realistic conflicts, as well as destructive conflicts and constructive conflicts. The conflict resolution in Rakyat Cirebon's media office was pursued by not repeating the same mistakes, fostering good communication, being aware of differences of opinion, accepting criticism, and providing motivation.
\end{abstract}

Keywords: Communication, Conflict, Conflict Management

\section{Pendahuluan}

Permasalahan dalam perusahaan sering kerap terjadi entah itu PHK, permintaan kenaikan gaji, jenjang karir yang jelas bahkan penyediaan fasilitas kantor pun menjadi permasalahan. Akibat yang timbul dari permasalahan itu yaitu adanya konflik di internal tubuh organisasi tersebut.

Konflik itu bisa terjadi karena berbeda persepsi antara satu dengan yang lainnya. Perbedaan persepsi ini dilatar belakangi dari kehidupan seseorang sebelumnya yang akan membentuk karakter pribadi yang berbeda.

Konflik secara etimologi berasal dari bahasa Inggris yaitu conflict, dari bahasa Latin configure yang berarti saling menjatuhkan atau konflik terjadi karena ada pihak-pihak yang saling bertentangan (Rusdiana 2016).

Secara terminologi, ada beberapa pengertian yang dijelaskan para ahli, antara lain: Afzalur Rahim menyatakan bahwa konflik dapat didefinisikan sebagai keadaan interaktif yang termanifestasikan dalam sikap ketidakcocokan, pertentangan, atau perbedaan dengan atau antara entitas sosial seperti individu-individu, kelompok-kelompok, atau organisasi-organisasi (Efendi 2015). Sedangkan Wahjosumidjo mendefinisikan konflik lebih simpel yaitu, "Segala macam bentuk hubungan antara manusia yang mengandung sifat berlawanan".

Perilaku seseorang dalam organisasi juga sangat berpengaruh pada berjalannya sebuah organisasi. Individu yang berasal dari organisasi yang berbeda dan kemudian harus bergabung dengan individu yang berasal dari organisasi lainnya dan tergabung menjadi anggota organisasi yang baru tidaklah mudah.

Mengendalikan konflik berarti menjaga tingkat konflik yang kondusif bagi perkembangan organisasi sehingga dapat berfungsi untuk menjamin efektivitas dan dinamika organisasi yang optimal. Konflik tidak baik dan tidak buruk, tergantung bagaimana cara orang mengelolanya. Jika dikelola dengan baik, konflik akan menghasilkan sesuatu yang baik, tetapi apabila dikelola dengan buruk maka konflik akan menghasilkan sesuatu yang buruk pula (Wirawan 2010).

Ada tiga sudut pandang terhadap konflik yang terjadi dalam organisasi, yaitu aliran tradisional, aliran behavioral, dan aliran interaksi. Pertama, aliran tradisional menyatakan bahwa konflik dipandang sebagai sesuatu yang jelek, tidak menguntungkan, dan 
selalu menimbulkan kerugian dalam organisasi. Oleh karena itu, konflik harus dihindari dan dicegah dengan cara menemukan sumbernya dan diatasi. Kedua, aliran behavioral memandang konflik sebagai sesuatu yang alamiah, wajar terjadinya dalam organisasi, karena tanpa dicipta, konflik mesti terjadi dalam organisasi. Atas dasar itu, konflik tidak selamanya merugikan, tetapi juga dapat menguntungkan bilamana dikelola dengan baik. Ketiga, aliran interaksi yang memandang konflik dalam suatu organisasi seharusnya diciptakan (dirangsang). Pandangan ini dilatarbelakangi oleh konsep bahwa "organisasi yang tenang, harmonis, penuh kedamaian, maka kondisinya akan menjadi statis, mandek (stagnasi) dan tidak inovatif. Akibat selanjutnya organisasi tidak dapat bersaing untuk maju (Soetopo 2016).

Penelitian ini akan menjelaskan bagaimana manajemen konflik yang ada di kantor Rakyat Cirebon. Harian Rakyat Cirebon menyajikan informasi seputar Cirebon, Indramayu, Majalengka dan Kuningan. Lahir pada 11-11-2011 bersamaan dengan peresmian Graha Pena Radar Cirebon. Alamat kantor Rakyat Cirebon Jl Perjuangan No 99 Majasem Kota Cirebon. Kode Pos 45154, Telp (0231) 8301677, Faks (0231) 8301678, email:rakyatcirebon@gmail.com.

Sejalan dengan tujuan pers selain kontrol sosial dan informatif, harian Rakyat Cirebon terus bergerak menjadi koran terdepan. Serta menjadi bacaan utama masyarakat, khususnya dalam pendidikan politik lokal. Ini sekaligus menjawab harapan masyarakat akan hadirnya media yang dapat menjadi referensi utama. Serta lengkap menyajikan berita-berita politik lokal, regional dan nasional dan berita-berita umum lainnya yang diperlukan masyarakat.

Rakyat Cirebon juga hadir untuk turut membangun wilayah Cirebon menjadi daerah yang maju dan terus berubah dengan ditunjang rnasyarakatnya yang melek informasi. Harian Rakyat Cirebon yang semula terbit 12 halaman kini sudah terbit regular setiap hari dengan 16 halaman dengan 4 halaman berwarna.

Selain sebagai Koran idealis, Rakyat Cirebon juga tampil sebagai Koran probisnis. Menampilkan berbagai informasi tentang ekonomi bisnis, finansial baik lokal, nasional, maupun internasional.

\subsection{Jenis-jenis Konflik}

Dalam komunikasi organisasi, komunikasi terjadi secara formal maupun infromal, namun pada prinsipnya membahas masalah masalah yang berhubungan dengan kedinasan. Penyebab komunikasi dalam organisasi menjadi tidak efektif adalah kelebihan atau kebanyakan informasi yang disampaikan, tingkat kerumitan pesan, penerimaan pesan ganda, perbedaan status, kurangnya kepercayaan, komunikasi yang tidak terstruktur, kesalahan pemilihan media, iklim komunikasi tertutup (Nurrohim 2009).

Konflik merupakan salah satu esensi dari kehidupan dan perkembangan manusia yang memiliki karakteristik yang beragam. Konflik merupakan hal yang tak terhindarkan. Manusia sedari awal penciptaanya memiliki sifat-sifat yang berbeda satu dengan yang lainnya. Wajar manusia memiliki asumsi yang berbeda terhadap suatu hal yang sama. 
Perbedaan pendapat, opini, dan persepsi ini merupakan sumber konflik. Konflik merupakan suatu peristiwa yang kerap terjadi dan kadang tidak bisa mengelak bahkan menghambat pencapaian tujuan organisasi.

Manajemen konflik (Wirawan 2010) merupakan proses pihak yang terlibat konflik atau pihak ketiga yang menyusun strategi konflik dan menerapkannya untuk mengendalikan konflik agar menghasilkan resolusi yang diinginkan.

\subsubsection{Konflik Personal dan Konflik Interpersonal}

Konflik interpersonal adalah konflik yang terjadi di dalam suatu organisasi atau konflik di tempat kerja. Konflik interpersonal adalah konflik pada suatu organisasi diantara pihak-pihak yang terlibat konflik dan saling tergantung dalam melaksanakan pekerjaan untuk mencapai tujuan organisasi.

\subsubsection{Konflik Interest}

Jenis konflik yang mempunyai ciri konflik individual dan konflik interpersonal adalah konflik kepentingan atau konflik interest. Konflik ini berkaitan dengan konflik dalam diri seorang individu dalam suatu altar sistem sosial (organisasi atau perusahaan) yang membawa implikasi bagi individu dan sistem sosialnya.

\subsubsection{Konflik Realistis dan Konflik Nonrealistis}

Lewis Coser seperti dikutip oleh Joseph P. Folger dan Marshal S. Pole (1984) mengelompokkan konflik menjadi konflik realistik dan konflik non realistik. Konflik realistis adalah konflik yang terjadi karena perbedaan dan ketidaksepahaman cara pencapaian tujuan atau mengenai tujuan yang akandicapai.

Konflik non realistis adalah konflik yang terjadi tidak berhubungan dengan isu substansi penyebab konflik. Konflik ini dipicu oleh kebencian atau prasangka terhadap lawan konflik yang mendorong melakukan agresi untuk mengalahkan atau menghancurkan lawan konfliknya.

\subsubsection{Konflik Destruktif dan Konflik Konstruktif}

Konflik juga dapat dikelompokkan menjadi konflik konstruktif (konflik produktif) dan konflik destruktif (konflik kontra produktif). Konflik konstruktif adalah konflik yang prosesnya mengarah kepada mencari solusi mengenai substansi konflik. Konflik jenis ini membangun sesuatu yang baru atau mempererat hubungan pihak-pihak yang terlibat konflik, ataupun mereka memperoleh sesuatu yang bermanfaat dari konflik.

Dalam konflik destruktif, pihak-pihak yang terlibat konflik tidak fleksibel atau kaku karena tujuan konflik didefinisikan secara sempit yaitu untuk mengalahkan satu sama lain.

\subsubsection{Konflik Menurut Bidang Kehidupan}

Konflik dapat dikelompokkan menurut bidang kehidupan yang menjadi objek konflik. Namun, seringkali, suatu jenis konflik tidak berdiri sendiri, melainkan berkaitan dengan konflik berkaitan dengan sejumlah aspek kehidupan. Sebagai contoh, konflik sosial seringkali tidak hanya disebabkan oleh perbedaan suku, ras, kelas, atau kelompok sosial, tetapi seringkali disebabkan oleh kecemburuan ekonomi, kehidupan politik, dan 
perbedaan agama.

\subsubsection{Demokrasi dan Konflik}

Dalam istilah demokrasi, proses manajemen konflik untuk menyelesaikan konflik juga terkandung, yaitu negosiasi, musyawarah, dan voting, serta, referendum dan pelaksanaan undang-undang. Solusi dari konflik dalam kerangka demokrasi adalah win \& win solution serta win \& losesolution.

\subsection{Faktor-faktor yang memengaruhi konflik}

\subsubsection{Komunikasi yang Tidak Baik}

Komunikasi yang tidak baik akan menimbulkan konflik dalam organisasi. Konflik yang bersumber dari komunikasi antara pimpinan dengan karyawan disebabkan salah pengertian yang berkenaan oleh kalimat, bahasa yang sulit dimengerti, atau informasi yang mendua atau tidak lengkap. Munculnya konflik dalam organisasi ini di latar belakangi oleh kepentingan orang per orang, terkait perbedaan pendapat, kesenjangan individu, dan kelompok.

\subsubsection{Saling Tergantung atau Interdependensi Tugas}

Konflik terjadi karena pihak- pihak yang terlibat konflik memiliki tugas yang tergantung satu sama lain. Jika saling ketergantungan tinggi, maka biaya resolusi konflik akan tingi. Jika saling ketergantungan rendah, maka biaya resolusi akan rendah.

\subsubsection{Perasaan dan Emosi}

Orang juga mempunyai perasaan dan emosi yang berbeda. Seseorang mengikuti perasaan dan emosinya saat berhubungan dengan sesuatu atau orang lain.

\subsection{Pengaruh Konflik}

Konflik memiliki pengaruh dalam kehidupan sehari-hari baik pengaruh negatif maupun positif, seperti berikut:

a. Memahami orang lain dengan baik

b. Menstimulus cara berpikir yang kritis dan meningkatkan kreativitas

c. Manajemen konflik dalam menciptakan solusi terbaik

d. Merusak hubungan dan komunikasi antara pihak-pihak yang terlibat konflik

e. Sikap dan perilaku yang negatif

f. Kesehatan.

\section{Metodologi Penelitian}

Mengacu pada karakteristik masalah yang telah disebutkan sebelumnya, penelitian ini dapat digolongkan dalam jenis penelitian deskriptif. Menurut Suharsimi, penelitian deskriptif dapat menjelaskan apa yang terjadi secara detail.

Adapun pendekatan yang digunakan dalam penelitian ini adalah pendeketan kualitatif (qualitative approach). Penelitian kualitatif menghasilkan data berupa kata-kata tertulis atau lisan dari orang-orang dan perilaku yang diamati (Moleong 1998). Sedangkan menurut Muhadjir (1996) penelitian kualitatif menyangkut penelitian dunia tingkah laku yang unik dari realitas sosial. 14 Dunia tingkah laku ini, diantaranya aspek intelegensi, minat, pandangan, penilaian, cita-cita, dan keinginan-keinginan; yang muncul dari orang dalam bentuk kata-kata. 
Implikasi penggunaan pendekatan kualitatif, sebagaimana dijelaskan Moleong (1998), bahwa (1) peneliti sendiri sebagai pelaku langsung yang melakukan pengamatan atau wawancara; (2) peneliti mengumpulkan dan mencatat data secara terperinci mengenai hal-hal yang bertalian dengan permasalahan yang diteliti; (3) peneliti mementingkan pandangan sumber apa adanya. Artinya, bagaimana mereka memandang, menilai dan menafsirkan dunia atas pendiriannya sendiri, sehingga tidak memaksakan pandangan subjektif peneliti ke dalamnya.

Sumber data dalam penelitian ini diperoleh melalui sumber kepustakaan dan sumber lapangan. Sumber kepustakaan diperlukan untuk merumuskan konsep dan teori yang digunakan dalam penelitian serta untuk mengungkapkan fakta-fakta terdahulu terutama yang terkait dengan komunikasi dan menejemen konflik. Tahap penentuan sumber kepustakaan dilakukan dalam dua hal. Pertama, tahap invertaris bahan dengan menghimpun selengkap-lengkapnya. Kedua, tahap pengelompokkan, yakni tahap pemilihan dan pemilahan sesuai dengan katagorisasi yang dibutuhkan.

Sumber data ditentukan berdasarkan teknik "bola salju". Dalam arti, sumber data diperoleh dari hasil rangkaian orang pertama, kedua, ketiga dan seterusnya, yang dirujuk secara berangkai. Oleh karena itu, sumber data diperoleh secara menggelinding.

Alat pengumpul data dalam penelitian adalah; pertama, studi kepustakaan, yakni mengumpulkan dan memilih data-data teoritik maupun data dari hasil penelitian terdahulu.
Tahapan-tahapan penelitian dengan pendekatan kualitatif ini dapat dibedakan ke dalam tiga tahapan sebagai berikut: pertama, tahap orientasi. Pada tahap ini dihimpun data secara umum berkenaan dengan masalah yang diteliti. Ia dilakukan melalui observasi dan wawancara secara umum dan terbuka agar dapat diperoleh informasi yang luas mengenai hal-hal yang umum tentang objek yang diteliti. Tahap ini juga disertai dengan menelaah sejumlah bahan kepustakaan yang dianggap relevan. Kemudian informasi itu dianalisis untuk mendapatkan hal-hal yang menonjol, menarik, penting, dan dianggap berguna untuk diteliti lebih lanjut secara mendalam.

Kedua, tahap eksplorasi. Pada tahap ini fokus penelitian sudah jelas sehingga dapat dihimpun data atau informasi yang lebih terarah dan spesifik. Baik observasi maupun wawancara. Pada tahap ini wawancara dilakukan secara struktur dan mendalam sehingga dapat diperoleh informasi yang lebih mendalam.

Ketiga, tahap member check. Tahap ini semua informasi yang diperoleh baik melalui pengamatan atau wawancara, dan sejak awal dianalisis, dituangan ke dalam bentuk laporan penelitian. Selanjutnya laporan itu dikomfirmasikan kepada informan agar diperoleh hasil penelitian yang lebih dipercaya. Pada tahap ini pula dilakukan perbaikan-perbaikan atau penelusuran informasi yang menurut informan kurang tepat.

Wawancara terhadap pemimpin redaksi serta karyawannya, ini dilakukan agar memenuhi kriteria dari teori-teori yang telah 
dijabarkan. Data yang didapatkan sangat efektif dan tepat dikarenakan berhadapan langsung dengan pimpinan redaksi dan wartawan media Rakyat Cirebon.

Adapun fokus penelitian yang kami lakukan yaitu:

a. Manajemen konflik

b. Penyebab konflik

c. Faktor-faktor yang memengaruhi konflik

d. Jenis konflik

e. Pengaruh konflik

Sebelum dilakukan analisis data, peneliti terlebih dahulu harus melakuka pemeriksaan keabsahan data. Pemeriksaan keabsahan data dilakukan berdasarkan kriteria, yaitu derajat kepercayaan (credibility), keteralihan (transferability), kebergantungan (dependability) dan kepastian (confirmability). Setelah dilakukan pemeriksaan keabsahan data, data selanjutnya dianalisis. Secara operasional, analisis data dilakukan dalam tiga langkah.

Pertama, reduksi data. Proses pereduksian data ke dalam bentuk uraian yang lengkap dan banyak. Data tersebut direduksi, dirangkum dan dipilih hal-hal yang pokok dan difokuskan ke dalam hal-hal yang dianggap penting sesuai dengan arah penelitian. Dari data tersebut dapat diperoleh gambaran yang tajam tentang hasil pengamatan dan wawancara.

Kedua, display data. Upaya pembuatan dan penyajian data melalui model, matriks dan grafik sehingga keseluruhan data serta bagian-bagian detailnya dapat dipetakan secara jelas. Hal ini dilakukan dengan pertimbangan bahwa data yang diperoleh merupakan kumpulan informasi yang sangat banyak sehingga dapat menimbulkan kesulitan dalam menggambarkan secara detail dan menyeluruh.

Ketiga, kesimpulan dan verifikasi. Penyusunan secara sistematis data yang telah terkumpul, baik melalui penentuan tema, model, matriks dan grafik. Selanjutnya disimpulkan sehingga dapat diperoleh makna data yang sesungguhnya. Karena kesimpulan pada tahap ini masih bersifat tentatif dan sangat umum, maka masih perlu diuji melalui data yang diperoleh baru.

\section{Hasil dan Pembahasan}

Penelitian ini kami lakukan di kantor Rakyat Cirebon dengan narasumber pimpinan redaksinya sendiri, bapak ling Casdirin. Rakyat Cirebon adalah salah satu surat kabar yang berdiri pada tanggal 11 November 2011.

Harian Rakyat Cirebon, bergerak di bidang pendidikan politik lokal maupun nasional. Dalam penelitian ini, kami mendapatkan beberapa hal mengenai manajemen konflik yang terjadi di Rakyat Cirebon selama kurang lebih 8 tahun berdiri.

Adapun jenis-jenis konflik yang terjadi di Rakyat Cirebon sesuai dengan teori dari buku Konflik dan Manajemen Konflik karya Wirawan (2010), yaitu:

a. Konflik Personal dan Konflik Interpersonal

Kedua konflik ini biasa terjadi dalam sebuah perusahaan, termasuk di kantor media Rakyat Cirebon. Konflik personal bisa saja terjadi kepada 
semua orang termasuk para karyawan. Contohnya saja, mereka sedang stres dengan pekerjaan atau dengan masalah pribadi lainnya sehingga menyebabkan pekerjaan mereka tidak sempurna dan bisa saja merugikan perusahaan.

Konflik interpersonal biasanya terjadi kepada dua pihak atau lebih. Misalnya saja sering terjadi di Rakyat Cirebon, konflik antar karyawan, karyawan dengan atasan, atau bahkan sebaliknya. Konflik ini biasanya disebabkan oleh ketidaksamaan dalam pemahaman.

b. Konflik Interest

Konflik ini sebenarnya tidak terjadi di Rakyat Cirebon, karena pimpinan redaksi sendiri tidak memiliki kesibukan lain seperti mengikuti organisasi atau kumpulan lain selain pekerjaannya di media. Sehingga tidak ada konflik yang diakibatkan oleh dua jabatan yang dikerjakan bersamaan.

Namun, pimpinan redaksi sendiri masih tetap seorang ayah dan suami. Sehingga beliau harus bisa menepatkan dirinya sebagai kepala keluarga dan pimpinan redaksi sekaligus. Jika beliau sedang di kantor menghadapi karyawannya, maka beliau harus menjadi pimpinan redaksi yang mempunyai tugas sebagai mana mestinya. Sedangkan jika beliau di rumah, maka beliau tidak bisa bersikap seperti seorang pimpinan redaksi terhadap anak istrinya.

c. Konflik Realistis dan Konflik
Nonrealistis

Senantiasa sering terjadi di kantor media Rakyat Cirebon yaitu konflik realistis. Mereka biasa menyelesaikan konflik ini dengan berkomunikasi, musyawarah, dan berdiskusi demi menyamakan pemahaman sehingga tidak ada perbedaan pendapat lagi diantara mereka.

d. Konflik destruktif dan konflik konstruktif

Di kantor media Rakyat Cirebon, jika terjadi konflik, mereka cenderung mengarah ke konflik konstruktif. Mereka lebih mencari solusi dan jalan keluar jika terjadi sebuah konflik daripada menentukan seorang pemenang. Mereka cenderung membicarakan masalah dengan baik sehingga hubungan antara pihak-pihak yang terlibat konflik bisa membaik kembali.

Dari hasil penelitian kami di kantor Rakyat Cirebon, diketahui ada beberapa faktor yang menjadi penyebab terjadinya konflik. Selain latar belakang budaya berbeda, salah satu penyebab munculnya konflik karena perbedaan nilai yang menjadi patokan tiap orang dalam berperilaku.

Nilai adalah arahan dalam berperilaku sehari-hari. Ketika karyawan bekerja dengan aktivitas kerja yang selaras dengan sesuatu yang mereka anggap penting, maka energi, motivasi, hasrat dan keinginan mereka pun akan muncul untuk mencapai tujuan tersulit sekalipun.

Sesuai dengan teori yang dipaparkan 
oleh Wirawan (2010) dalam bukunya yang berjudul konflik dan manajemen konflik, ada beberapa faktor yang memang biasanya menjadi penyebab konflik itu datang dalam sebuah perusahaan. Faktor-faktor tersebut diantaranya:

a. Komunikasi yang Tidak Baik

Komunikasi yang tidak baik akan menimbulkan konflik dalam organisasi. konflik yang bersumber dari komunikasi antara pimpinan dengan karyawan disebabkan salah pengertian yang berkenaan oleh kalimat, bahasa yang sulit dimengerti, atau informasi yang mendua atau tidak lengkap. Munculnya konflik dalam organisasi ini di latarbelakangi oleh kepentingan orang perorang, terkait perbedaan pendapat, kesenjangan individu, dan kelompok. Senada dengan penelitian dari George Iordanides and Sotiri.

Muspawi (2014) Hasil penelitian menunjukkan bahwa efek negatif dari konflik termasuk gangguan hubungan interpersonal, yang berkontribusi pada penurunan kualitas komunikasi dan kurangnya koordinasi. Makna yang dapat diperoleh ialah, dalam organisasi, komunikasi memiliki peran penting, terutama dalam membentuk organisasi yang efektif dan efisien, makin baik komunikasi mereka, makin baik pula kerja sama mereka.

b. Saling tergantung atau interdependensi tugas
Konflik terjadi karena pihak-pihak yang terlibat konflik memiliki tugas yang tergantung satu sama lain. Jika saling ketergantungan tinggi, maka biaya resolusi konflik akan tingi. Jika saling ketergantungan rendah, maka biaya resolusi akan rendah. Jadi, konflik terjadi di antara pihak yang saling membutuhkan satu sama lain tanpa konsekuensi negatif., tahapan proses kerja jurnalistik tugas yang ada di Rakyat Cirebon berlaku saling ketergantungan satu sama lain, hal ini terjadi ketika seorang wartawan terlambat menyelesaikan tugasnya menulis berita, maka akan menyebabkan keterlambatan pihak editing dalam melakukan tugasnya.

c. Mengenai ketergantungan Perasaan dan Emosi

Faktor emosi paling sering terjadi dalam sebuah perusahaan. Misalnya saja, yang dipaparkan oleh narasumber kami, bahwa seringkali konflik terjadi antar sesama karyawan perusahaan disebabkan oleh keadaan emosi mereka yang sedang tidak baik atau stabil. Ketika mereka mempunyai masalah di luar pekerjaan, maka kondisi emosi mereka akan memengaruhi proses kerja sehingga menimbulkan konflik dengan karyawan lain.

Konflik itu wajar adanya, manusia memiliki karakter dan ego yang berbeda- beda. Inilah yang menyebabkan sering terjadinya konflik, entah interpersonal maupun konflik 
lainnya. Konflik interpersonal di Rakyat Cirebon, biasanya disebabkan oleh emosi antar karyawan. karena dalam perusahaan, karyawan memiliki karakter yang berbeda, sehingga sangat mungkin untuk timbulnya suatu konflik.

Bapak ling juga membeberkan bagaimana cara dirinya menyelesaikan atau mencegah terjadinya konflik, baik antar sesama karyawan Rakyat Cirebon maupun dengan pihak luar. Salah satu cara beliau menyelesaikan sebuah konflik di dalam kantor yaitu dengan komunikasi. Beliau dengan karyawan-karyawannya harus terus menjalin komunikasi yang ramah sehingga kemungkinan terjadi kesalahpahaman satu sama lain menjadi sangat kecil.

Beliau biasa mengobrol dan menjalin kedekatan dengan pegawai- pegawainnya, selain untuk menghindari terjadinya konflik, juga agar para karyawannya merasa nyaman bekerja di sana bersama beliau.

Beliau juga tidak segan-segan bercanda dan bergurau bersama karyawankaryawannya saat bekerja. Terbukti saat kita melakukan penelitian, beliau yang sedang memantau langsung karyawan-karyawannya saat bekerja, beliau dengan iseng nya sesekali menggoda karyawan- karyawannya yang sedang sibuk dengan komputer mereka. Namun, selain itu, karyawannya- karyawannya pun tidak kalah berani dalam hal menggoda sang atasan. Sehingga dalam ruang kerja mereka seringkali terlontar lelucon-lelucon yang menurut mereka bisa menjadi penawar rasa lelah karena memang mereka biasa bekerja malam, tepatnya dari jam 8 malam hingga jam 12 malam.

Selain mengobrol dan bercanda secara langsung, bapak Iing pun menunjukkan sebuah group chat dalam aplikasi whatsapp yang berisikan dirinya dan karyawan- karyawan Rakyat Cirebon. Menurut beliau, aktif dalam group chat itu membuat ia dan karyawannya bisa memantau dan mengetahui kabar satu sama lain. tentu saja tujuannya untuk mempererat hubungan antar karyawan dan menjadikan mereka lebih akrab satu sama lain.

Namun, konflik dalam perusahaan tidak hanya berputar-putar antara karyawan satu dengan lainnya, antara atasan dengan bawahannya ataupun sebaliknya, tetapi juga bisa saja konflik terjadi dengan pihak luar. Baik itu media lain yang berarti pesaing, atau bahkan bisa saja terjadi konflik dengan narasumber atau audiens.

Menurut bapak Iing, konflik dengan media pesaing tidak jauh dari bersaing untuk mendapatkan berita dan menjadi media cetak terbaik. Mereka terus berlomba-lomba untuk menjadi satu- satunya surat kabar terbaik sehingga mengharuskan mereka untuk bersaing dalam hal mencari berita, agar satu diantara mereka menjadi paling aktual dan terpercaya.

Sebenarnya, persaingan seperti ini wajar adanya dalam sebuah perusahaan, yang sama-sama bergelut di bidang media, tetapi selain dari persaingan seperti itu, Rakyat Cirebon sangat menghindarinya.

Mereka menghindari konflik-konflik berat dengan perusahaan media lain atau pesaing, karena menurut mereka, mereka itu saling membutuhkan satu sama lain. Cara 
Rakyat Cirebon dalam menghindari konflik dengan pihak luar termasuk pesaing yaitu dengan membina atau menjaga hubungan dengan baik, membangun relasi dan mempertahankannya.

Konflik dengan pihak luar juga tidak hanya sebatas dengan para pesaing saja, tetapi juga dengan narasumber bahkan dengan audiens. Konflik dengan narasumber biasanya ketika salah memuat keterangan dalam berita, atau ada kekeliruan dalam penulisan berita sehingga dapat merugikan narasumber. Konflik seperti ini bisa diselesaikan dan bahkan ada undang-undang yang mengaturnya.

Undang-undang tersebut yaitu undangundang pers yang memberikan kesempatan kepada narasumber untuk memberikan jawaban dan tanggapan atas pemberitaan yang salah.

Dalam pasal 1 angka 13 UU pers juga disebutkan bahwa, kewajiban koreksi adalah keharusan melakukan koreksi atau ralat terhadap suatu informasi, data, fakta, opini, atau gambar yang tidak benar yang telah diberitakan oleh pers yang bersangkutan. Kewajiban koreksi ini juga merupakan bentuk tanggung jawab pers atas berita yang dimuatnya. Hal ini juga bisa menyelesaikan konflik dengan audiens yang mengeluh tentang data atau info yang tidak valid.

Setelah memaparkan berbagai konflik yang pernah dan mungkin saja terjadi lagi, bapak Iing memberikan beberapa dampak positif dan negatifnya dari konflik yang terjadi selama ini, yaitu dampak positifnya bisa dijadikan sebuah pelajaran untuk menemukan solusi dan tidak terlibat dalam konflik yang sama sebanyak dua kali. Untuk dampak negatifnya, beliau membicarakan tentang karyawannya yang terkadang merasa pekerjaannya tidak adil dan beberapa pihak yang pasti merasa dirugikan. Namun, beliau menyebutkan bahwa konflik tidak terlalu berdampak berarti bagi mereka karena mereka selalu berusaha menyelesaikannya dengan baik dan membina komunikasi satu sama lain.

Menurut Stevenin (dalam Anwar 2015) terdapat lima langkah dalam meredakan konflik yaitu: 1) Pengenalan kesenjangan antara keadaan yang ada diidentifikasi dan bagaimana keadaan yang seharusnya, 2) Diagnosis, menguji mengenai siapa, apa, mengapa, dimana, dan bagaimana berhasil dengan sempurna. Memperhatikan masalah utama yang terjadi, 3) Menyepakati suatu solusi, mengumpulkan masukan untuk mencari solusi atau jalan keluar dan menyaring penyelesaian yang tidak dapat diterapkan atau tidak praktis, 4) Pelaksanaan, dengan konsekuensi adanya keuntungan dan kerugian, 5) Evaluasi, jika penyelesaiannya tampak tidak berhasil, kembalilah ke langkah-langkah sebelumnya dan cobalah lagi.

Salah satu srategi yang dilakukan dalam mengatasi dan menyelesaikan konflik di Rakyat Cirebon adalah negosiasi. konflik dengan narasumber terjadi ketika salah memuat keterangan dalam berita, atau ada kekeliruan dalam penulisan berita sehingga dapat merugikan narasumber. Konflik seperti ini bisa diselesaikan dengan cara negosiasi. Pihak Rakyat Cirebon memberikan 
kesempatan kepada narasumber untuk memberikan jawaban dan tanggapan atas pemberitaan yang salah, yang kemudian berita tersebut akan di muat ulang oleh pihak Rakyat Cirebon. Metode ini dirasa efektif karena mendapatkan kesepakatan dan jalan keluar dari konflik tersebut. Jadi tidak adalagi salah satu pihak yang merasa dirugikan.

Menilai Kriteria Keberhasilan Konflik:

a. Tidak Mengulangi Kesalahan yang Sama.

Melakukan tindakan pencegahan konflik jika terjadi kejadian yang sama di kemudian hari, dengan mendata kejadian tersebut sehingga tidak terjadi kembali.

b. Membina Komunikasi yang Baik Hal-hal yang dilakukan di Rakyat Cirebon adalah memberikan kemudahan kepada karyawannya dalam berkomunikasi dengan menyediakan media komputer, dan memperbolehkan karyawannya menggunakan handphone agar kinerja kerja yang dihasilkan lebih cepat dan maksimal.

Selain itu, pemimpin redaksi selalu berusaha menjalin komunikasi dengan baik dengan karyawannya untuk menghindari adanya kendala dalam hal pekerjaan yang sedang ditangani dan pemimpin redaksi akan memberikan masukan terhadap masalah yang dihadapi oleh karyawannya. Seperti aktif dalam group chat itu membuat ia dan karyawannya bisa memantau dan mengetahui kabar satu sama lain.
Tentu saja tujuannya untuk mempererat hubungan antar karyawan dan menjadikan mereka lebih akrab satu sama lain.

c. Menyadari Perbedaan Pendapat Memiliki pendapat pribadi merupakan wajar adanya seperti yang terjadi di Rakyat Cirebon, baik pemimpin redaksi maupun antar karyawan selalu berpikiran terbuka atas perbedaan pendapat. Hal ini dilakukan dengan menyadari perbedaan pendapat akan berdampak pada pertumbuhan dan perkembangan kerja tim menjadi lebih baik.

d. Menerima Kritik.

Di Rakyat Cirebon pemimpin redaksi maupun karyawan sangat terbuka akan kritikan yang masuk, terlebih kritikan terhadap performa kerja, hal ini penting untuk perkembangan karier dan karakter diri dan dengan hal tersebut bisa mengambil kritikan sebagai pelajaran.

e. Pemberian Motivasi.

Upaya yang dilakukan pemimpin redaksi di Rakyat Cirebon dalam memotivasi karyawannya adalah dengan memelihara hubungan sosial yang baik dengan karyawannya dan juga senantiasa membangun suasana kerja yang positif dan menyenangkan, terbukti saat kita melakukan penelitian, beliau sedang memantau langsung karyawan- karyawannya saat bekerja, beliau dengan iseng nya sesekali menggoda dan bergurau saat karyawan 
karyawannya yang sedang sibuk dengan komputer mereka.

Peneliti menemukan beberapa cara penanganan konflik yang diterapkan di Rakyat Cirebon diantaranya adalah:

a. Mengumpulkan data secara empiris yang didapat dari penelusuran masalah baik data secara tertulis maupun hasil narasumber.

b. Musyawarah dengan mempertemukan pihak- pihak yang melakukan konflik dengan mencocokkan data atau informasi yang didapat untuk memecahkan masalah yang terjadi.

c. Diskusi dengan cara mencari solusi secara bersama-sama dengan berdialog terhadap masalah yang terjadi.

d. Kompetisi. Ketika karyawan ingin berhasil, mereka terdorong untuk bereksperimen dengan pendekatan yang mengarah pada hasil yang lebih baik. Mereka menargetkan dirinya supaya berhasil dan hal ini memotivasi kreativitas dalam dirinya. Kreativitas ini mengarah pada peningkatan produktivitas. Hal ini terjadi di Rakyat Cirebon ketika antar wartawan bersaing untuk mencapai target maksimal dalam menulis berita. Maka ia mencoba berbagai alternatif cara untuk mendapatkan berita yang banyak, informatif dan akurat. Selain itu kompetisi juga terjadi dengan pesaing media cetak pihak luar, Rakyat Cirebon terus berupaya meningkatkan mutu kualitas agar mendapat berita yang aktual dan menjadi media cetak terbaik.

\section{Simpulan}

Sebuah perusahaan tidak luput dari adanya konflik selama perjalanan karirnya. Konflik bisa terjadi orang dalam atau temanteman kantor bahkan atasan, bisa juga terjadi dengan pihak luar perusahaan yang memang masih berkaitan dengan perusahaan tersebut.

Seperti hal nya di kantor media Rakyat Cirebon, konflik terjadi antar karyawan bahkan dengan atasan, ada pula konflik yang terjadi dengan pihak luar yaitu narasumber, karena memang Rakyat Cirebon adalah sebuah kantor perusahaan media cetak sehingga tidak luput dari yang namanya wartawan, wawancara, dan narasumber.

Dampak dari terjadinya sebuah konflik ini cukup beragam, ada yang menimbulkan kerugian terhadap perusahaan tetapi dibalik kerugian itu terkadang ada saja hal yang dapat menjadi pelajaran bahkan memicu perusahaan tersebut menjadi lebih besar. Dampak dari konflik bisa dirasakan tergantung bagaimana perusahaan tersebut menanganinya.

Di Rakyat Cirebon sendiri, dampak dari sebuah konflik tidak terlalu berarti karena memang mereka menangani masalah dengan cukup baik. Penanganan atau bahkan pencegahan agar mereka tidak terlibat dalam konflik salah satunya yaitu dengan menjalin komunikasi yang baik antara satu dengan lainnya. Menurut pimpinan redaksi mereka, komunikasi adalah salah satu kunci untuk terus menciptakan keharmonisan di perusahaan. 


\section{Daftar Pustaka}

Anwar, Choerul. 2015. "Manajemen Konflik Untuk Menciptakan Komunikasi Yang Efektif." Jurnal Interaksi 4 (2): 148-157.

Efendi, Nur. 2015. Islamic Educational Leadership.Yogyakarta: Kalimedia.

Moleong, Lexy J. 1998. Metodologi Penelitian Kualitatif. Bandung: PT Remaja Rosdakarya, Cet. IX.

Muhadjir, Noeng. 1996. Metodologi Penelitian Kualitatif. Yogyakarta: Rake Sarasin.

Muspawi, Mohamad. 2014. "Manajemen Konflik (Upaya Penyelesaian Konflik dalam Organisasi)." Jurnal Penelitian Universitas Jambi Seri Humaniora 16 (2): 41-46.

Nurrohim, Hassa. 2009. "Efektivitas Komunikasi dalam Organisasi." Jurnal Manajemen 7 (4).

Rusdiana. 2015. Manajemen Konflik. Bandung: Pustaka Setia.

Soetopo, Hendyat. 2016. Perilaku Organisasi Teori dan Praktik di Bidang Pendidikan. Bandung: Rosda.

Wahjosumidjo. 2002. Kepemimpinan Kepala Sekolah Tinjauan Teoritik dan Permasalahannya. Jakarta: PT. Raja Grafindo Persada.

Wirawan. 2010. Konflik dan Manajemen Konflik Teori, Aplikasi, dan Penelitian. Jakarta: Penerbit Salemba Humanika. 